\title{
First Observation of MTHFR 678 C-A (Ala222Ala) Single Nucleotide Polymorphism
}

\author{
MTHFR C678A (Ala222Ala) Tek Nükleotid Değissiminin \\ İlk Kez Saptanması
}

\author{
Yonca Eğin, Nejat Akar \\ Ankara University, School of Medicine, Department of Pediatric Molecular Genetics, Ankara, Turkey
}

\section{To the Editor,}

The enzyme methylenetetrahydrofolate reductase (MTHFR) plays a key role in folate metabolism. MTHFR catalyses NADPH-linked reduction of $\mathrm{N}^{5,10}$-methylenetetrahydrofolate to $\mathrm{N}^{5}$-methylene tetrahydrofolate. The MTHFR gene exhibits 2 common genetic polymorphisms (C677T and A1298C). The MTHFR 677 C to T substitution converts alanine to a valine residue, resulting in a thermolabile enzyme [1]. A reduction in MTHFR activity leads to an elevated plasma homocysteine level, which has been implicated as a risk factor for vascular and thromboembolic disease [2-4].

Real-time polymerase chain reaction (RT-PCR) facilitates quantification of polymorphic DNA regions and genotyping of single nucleotide polymorphisms (SNPs), including MTHFR C677T base substitution. The system is optimized to detect the difference in the $\mathrm{T}_{\mathrm{m}}$ of the mutant and the wild-type allele using commercially available primers and hybridization probes [5]. Recently, MTHFR C685G (Iso225Val) and G679A (Asp223Asn) mutations other than the common MTHFR C677T were reported based on different melting points and RT-PCR [6], with an allele frequency of 1 in 3000-4000 samples [5].

A male patient's DNA was isolated using a MagnaPure automatic isolation system (Roche Diagnostics, Indianapolis, USA). Genotyping of the MTHFR C677T polymorphism was performed via RT-PCR and fluorescence melting curve detection analysis using a LightCycler sys- tem (Roche Diagnostics, Manheim, Germany). Written informed consent was provided by the patient.

The PCR product was purified using a Wizard SV PCR clean-up system (Promega, Madison, WI, USA), and sequenced using a CEQ Dye Terminator Cycle sequencing kit and a CSQ 8000 genetic analysis system (Beckman Coulter, Brea, CA, USA). Nucleotide changes were confirmed via a new PCR reaction, followed by sequencing analysis

The patient had an unusual RT-PCR analysis melting point profile. The patient's DNA was further analyzed via DNA sequencing, which showed a nucleotide change at $678 \mathrm{C}>\mathrm{A}$ that does not lead to an amino acid change (AlaAla). This polymorphism was not previously reported. Retrospectively, 4100 samples from our laboratory's archives were analyzed, but none of these samples had an MTHFR 678C-A change.

Research has shown that worldwide there is great variation in the prevalence of the MTHFR 677C-T mutation $[2,7,8]$. Several laboratory techniques are used to detect MTHFR C677T; the most common and reliable technique is melting point analysis, which can differentiate variants that lie within the region of the target probe. Differences in the base composition and nucleotide position affect $T_{m}$ in wild-type and target mutations. Variants with $\mathrm{T}_{\mathrm{m}}$ shifts of $2-5^{\circ} \mathrm{C}$ are easily visualized during experiments, as was the case of MTHFR and other thrombophilia genes $[5,9,10]$.

Address for Correspondence: Yonca EĞİN, M.D.,

Ankara Üniversitesi Tıp Fakültesi, Pediatrik Moleküler Genetik Bilim Dalı, Dikimevi, 06100, Ankara, Turkey

Phone: +90 3125956348 E-mail: yonca_egin@yahoo.com

Received/Geliş tarihi : May 26, 2010

Accepted/Kabul tarihi : June 17, 2010 
In the present study we reported a new heterozygous MTHFR gene polymorphism (678 C>A), with an unusual melting point profile. Although rare, the finding of MTHFR $678 \mathrm{C}>\mathrm{A}$ polymorphism indicates that this might be technically important, as it may lead to erroneous reporting.

\section{Conflict of Interest Statement}

The authors of this paper have no conflicts of interest, including specific financial interests, relationships, and/ or affiliations relevant to the subject matter or materials included.

\section{References}

1. Frosst P, Blom HJ, Milos R, Goyette P, Sheppard CA, Matthews RG, Boers GJ, den Heijer M, Kluijtmans LA, Van den Heuvel LP, Rozen R: A candidate genetic risk factor for vascular disease: A common mutation in methylenetetrahydrofolate reductase. Nature Genet 1995; 10: 111-113

2. Guba SC, Fink LM, Fonseca V: Hyperhomocysteinemia. An emerging and important risk factor for thromboembolic and cardiovascular disease. Am J Clin Pathol 1996; 106: 709-722

3. Clarke R, Daly L, Robinson K, Naughten E, Cahalane S, Fowler B, Graham I: Hyperhomocysteinemia: an independent risk factor for vascular disease. $N$ Eng J Med 1991; 324: 1149-1155
4. Boers GH, Smals AG, Trijbels FJ, Fowler B, Bakkeren JA, Schoonderwaldt HC, Kleijer WJ, Kloppenborg PW: Heterozygosity for homocystinuria in premature peripheral and cerebral occlusive arterial disease. N Engl J Med 1985; 313: 709-715

5. Lyon E: Discovering rare variants by use of melting temperature shifts seen in melting curve analysis. Clin Chem 2005; 51: 1331-1332

6. Erali M, Schmidt B, Lyon E, Wittwer C: Evaluation of electronic microarrays for genotyping factor $\mathrm{V}$, factor II and MTHFR. Clin Chem 2003; 49: 732-739

7. Schneider JA, Rees DC, Liu YT, Clegg JB: Worldwide distribution of a common methylenetetrahydrofolate reductase mutation. Am J Hum Genet 1998; 62: 1258-1260

8. Bourouba R, Houcher B, Djabi F, Egin Y, Akar N: The Prevalence of Methylenetetrahydrofolate Reductase 677 C-T, Factor V 1691 G-A, and Prothrombin 20210 G-A Mutations in Healthy Populations in Sétif, Algeria. Clin Appl Thromb Hemost 2009; 15 (5): 529-534

9. Ozdag H, Egin Y, Akar N: Prothrombin gene 20209 $\mathrm{C}>\mathrm{T}$ along with the first description of a homozygous polymorphism at the 3 ' downstream region $+4 \mathrm{C}>\mathrm{T}$ in the Turkish population. Lab Hematol 2006; 12 (3): 131-133

10. Mahadevan MS, Benson PV: Factor V Null Mutation Affecting the Roche Light Cycler Factor V Leiden Assay. Clin Chem 2005; 51: 1533-1535 